\title{
Global Economic Crisis Due to Novel Coronavirus (COVID-19): Challenges and Overcome for Bangladesh Economy
}

\author{
Md. Abdullah Shihab ${ }^{1} \quad$ Ariful Islam²* \\ 1. Deputy Director, Bangladesh Bank, Motijheel, Dhaka 1000, Bangladesh \\ 2. Lecturer, Department of Economics, Rabindra University, Shahzadpur, Sirajganj, Bangladesh
}

Note: The views, thoughts and recommendations of this study belong to the authors, and not necessarily to the authors' employer or organization.

\section{Abstract}

A genre of virus family is Coronavirus (COVID-19). In the contemporary world, there are multi-dimensional effects of disastrous COVID-19 pandemic. It may include social, economic and non-economic, cultural, physical (i.e. mortality \& morbidity), mental effects and so on. Nonetheless, using mostly secondary data sources, this article as an immediate and quick response endeavor to analyze the unanticipated and awful economic impact only of Novel Coronavirus (COVID-19) -a pandemic around the globe in two major broad segments. In the first segment, the global economic adverse effects are meant to be covered thoroughly and in the later segment, the upshot Coronavirus outbreak in Bangladesh economy is explained with the probable shift of its linkage with other development partners. The last but not the least, some policy prescriptions made by both international and national authorities are critically stated on theoretical economic background. Finally, some plausible and relevant recommendations are made to overcome this war-like situation using limited available studies on the economic effects of this deadly virus. As this article is attempted in the time when the whole impacts are undergoing, only partial scenarios of effects can be pictured from this writing. In conclusion, it is said that integrated and synchronized policy actions both internal and external stakeholders are the key factors to resist this unparalleled crisis.

Keywords: Novel Coronavirus, Quarantine, Economic Shock, World Economy, Bangladesh Economy, Economic Recovery.

DOI: $10.7176 / \mathrm{JESD} / 11-10-10$

Publication date:May $31^{\text {st }} 2020$

\section{Introduction}

Since the beginning of the twenty-first century, the world has been experiencing several pandemics such as Severe Acute Respiratory Syndrome (SARS) in 2002, N1H1 (Bird flu) in 2009, Middle East Respiratory Syndrome (MERS) in 2012, Ebola in 2013-14 and recently COVID-19 in 2019. Therefore, as a new infectious novel virus of the SARS category named SARS-CoV-2 coronavirus (COVID-19) is claimed to be naturally originated from a city of Wuhan, China in 2019 now being watched as a pandemic by World Health Organization (WHO) around the world. As of the first week of April 2020, this virus affected more than 204 countries and territories around the world and 2 international conveyances which are making a threat to human existence regardless of geographical area (Worldometers.info 2020) and the number of fatalities are increasing for no specific period as the vaccine is yet to be invented. This dangerous and exponentially deadly virus not only causing severe health hazards but also has a terrible adverse impact on socio-economic aspects of human life in various countries around the globe. In this critical scenario, in support of four former chief economists of the International Monetary Fund (IMF), Antonio Guterres, the chief of United Nations (UN) reckons a global recession of record dimension in near future (World Economic Forum 2020a). The economic growth of the world would come to standstill as the behavioral patterns of consumers and producers will drastically be influenced by the discouragement of regular activities of the people to tackle the pandemic. World economic growth, consumption, investment, production, trade, tourism, lifestyle, and the whole financial system underwent thorough acute volatility and extreme uncertainty. Nevertheless, Bangladesh, as an emerging developing and the densely populated country as well as an integral part of world trade is also experiencing unprecedented multi-spiked both internal and external pressures on different time-bound plans and programs of sustainability due to disruption of regular economic activities by forcible quarantine of all kinds of economic agents throughout the country more than a month from mid-March to last week of April 2020. This unexpected scenario, in turn, is making every single part of the economy of Bangladesh a deep scar and pushing to a sudden economic slowdown. Experts believe that Bangladesh will be affected in different macroeconomic variables such as Gross Domestic production (GDP) and its growth, Revenue Collection, both Non-development and Development Expenditure plans including Annual Development Program and other expenditures, Budget Deficit, Budget Financing and overall Balance of Payments i.e. Export and Import, Total Reserve, Foreign Direct Investment (FDI), Remittance and their growth rate. Now a big question arises as to how far Bangladesh as an emerging fast-growing country will be affected, how much the maximum cost she has to bear and whether she is capable of tackling this shock and how it can sustain the upward trend of its development. This 
article will try to address the tentative answers to all the questions along with the policy prescriptions of the recovery as a way out.

\section{Literature Review}

Only a few studies have been conducted so far about the economic impact of Coronavirus (CoV-19) globally. Among them, Ayittey and et al. (2020) studies on "Economic impacts of Wuhan 2019-nCoV on China and the world" and according to their findings, this viral disease disrupted China by attacking Wuhan, one of the core business hubs, by halting retailing, hospitality, tourism and trade. According to some experts, China may experience a loss of $\$ 62$ billion and 4.5\% GDP growth fall compared to that of last year. Further, China is very closely connected with other major economically affluent countries in the world, in effect, it may lose over $\$ 280$ billion and roughly $0.42 \%$ of GDP in the first quarter of 2020 .

The global economic cost of SARS analyzes by Lee and McKibbin (2004) using the modeling technique in a follow up of a workshop titled "Learning from SARS: Preparing for the Next Disease Outbreak" held on September 30 and October 1, 2003. They found that the economic cost of the deadly virus depends on the diseases-led behaviors of people within economies as well as a disease-facilitated change in expectations of people reflected in the market and non-marketed activities. A simulation of the G-cubed model estimated around $\$ 40$ billion loss of the world due to the epidemics of the last SARS virus in 2003.

In the modern world of strongly connected and integrated economy, McKibbin \& Fernando (2020), tries to roughly estimate the probable economic cost of COVID-19 under certain epidemiological assumptions in seven different cases considering shocks to labor supply, the equity risk premium of economic sectors, the cost of production in each sector, consumer demand, cost of production. The worst-case scenario projected that there will be 15 million deaths approximately and a loss of around 2.2 trillion world GDP. Moreover, they recognized this outbreak is a demand management and multi-faceted problem which requires longer-term fiscal, monetary and health policy response along with social distancing (i.e. quarantine).

McCloskey \& Heymann (2020) states that an analyst from the experience of SARS and MERS assessed a decline of $0.8 \%$ of real GDP if the pandemic is controlled within 3 months or a $1.9 \%$ fall if it lasts for 9 months holding other things are constant.

In respect of South Asia, a paper by Koshle and et al. (2020) explained the economic dependence of India. According to them, hospitality, aviation, tourism and trade will be primarily affected in the short run. However, the degree of economic cost is not properly outlined. A similar kind of work is found for the Nepalese economy by Koirala \& Acharya (2020).

As of now, the papers on the economic impact of this viral disease (COVID-19) on Bangladesh's economy is very rare to find. However, several national and international organizations attempt to forecast this. Such as, Bangladesh may lose a trade of \$16 million (UNCTAD 2020a). The duration of recession as of consequence of pandemic has a significant impact on Bangladesh as it's economy greatly dependent on other countries that influence readymade garments and remittance of Bangladesh (IMF 2020a). Bangladesh may lose around 1.1\% of the country's total economic output if this outbreak lingers more than six months (ADB 2020a).

In essence, presently it is tough to measure economic cost still the current paper tries to cover the influence and cost of the interdependence of the world economies and Bangladesh with updated data that captures the possible adverse impact of Coronavirus.

\section{Methodology}

The article is on the contemporary and scorching issue, a qualitative and descriptive approach with all the possible and available secondary data of both national and international sources such as articles, reports, outlooks and other COVID-19 related kinds of literature are meticulously taken into consideration. Besides, to describe the probable effects on different macroeconomic variables, conventional macroeconomic theory related to aggregate demand and aggregate supply, money, interest is considered. Additionally, the latest information in day to day basis is attempted to be incorporated up to 15th April 2020 for the transparency and acceptance of the article.

\section{Probable Global Economic Impact of Coronavirus:}

Every economic shock causes short-term and long-term effects. Rightly, it is difficult to predict the global economic impact in this short period when the virus is spreading from countries to countries within days leaving all the economies in total lockdown with some limited exceptions. In the meantime, according to experts the immediate direct impacts of virus breakout may have the following-

4.1. Reduction of World GDP: A sharp rise of new infectious disease forces to decrease in economic activities worldwide which in turn influences reduction in investment that provokes unemployment and declining of the consumption except necessary goods inducing a reduction in world GDP. In the face of global shock due to the Coronavirus effect, the World Bank (WB) projected slow growth of 2.1\% in the East Asia Pacific region (WB 2020a). International Monetary Fund (IMF) believes this COVID-19 has a recessionary effect on the world 
economy (IMF 2020b). An analysis of the UN Department of Economic and Social Affairs (DESA) perceived in the worst case that the world economy could contract almost a 1\% percent point in 2020 (UNDESA 2020). According to ADB (2020b), the global economic cost of a pandemic could be between $\$ 2.0$ trillion to $\$ 4.1$ trillion which is equivalent to $2.3 \%$ to $4.8 \%$ of global gross domestic product. Besides, OECD Interim Economic Assessment projected a reduction of $2.4 \%$ as a whole and a negative growth in the first quarter of 2020 (OECD 2020a). These predictions wave out severe damage to the world economy and its growth in a longer timeline.

4.2. A Downfall of World Financial System: Due to this pandemic, the world financial chain fell into disruption and ambiguity. Lack of certainty, security and confidence of the investors, the stocks of China, USA, Europe and Asia drastically lost approximately $\$ 5$ trillion in the last week of February 2020 (NBC News 2020). Additionally, the market of bonds became volatile with price and yields uncertainty. On the other hand, IEA projected a reduction in world oil demand by $1.1 \mathrm{mb} / \mathrm{d}^{1}$ in the first quarter of 2020 and by $345 \mathrm{~kb} / \mathrm{d}^{2}$ in the second quarter of 2020 . This reduction of demand caused by transport restrictions likely to reduce crude oil prices by $20 \%$ (IEA 2020). But this reduction will not be enjoyed by the confined consumers around the world because of the pandemic. On the contrary, the oil sellers will fall in a great financial loss as long as the virus remains fatal.

4.3. A Drop in World Trade: International trade forecast is frequently being adjusted because of the COVID-19 crisis which provokes global supply as well as demand shock. Fifty billion of exports have been lost from the global value chain on account of coronavirus outbreak (UNCTAD 2020b). China, the epicenter of the virus, is the second-largest economy in the world which at present contributes around 39\% in global economic growth and around 16.3\% in the world's GDP (Ayittey and et al., 2020). Therefore, disruption in China and other countries with major economies will significantly affect international trading. United Nations (UN) expects a decline in Foreign Direct Investment (FDI) by 30\% to $40 \%$ during 2020 (UNCTAD 2020c). The director-general of world trade organization (WTO), Roberto Azevêdo recognized this condition as a global socio-economic crisis and mentioned that the international trade of goods and services may be affected from $20 \%$ to $32 \%$ compared to that of 2019 depending on inclusive coordinated policy actions taken (WTO 2020).

4.4. A threat to the World Health System: The most direct impact of COVID-19 is on the health system of the world. Because of the spread, severity and alarming levels of mutation, the World Health Organization (WHO) characterized COVID-19 as pandemic (WHO 2020). Millions of people especially adult and older people have been suffering and dying in the lack of proper awareness, preparedness, treatment, antidotes and remedies and this race of deaths is increasing at an exponential rate every day. The number of infected persons regardless of gender and age is also high because of continuous transmission. In a word, the world health system has just collapsed. Therefore, such type of panicked situation visibly raises the question of health safety for the present and future world. Whatever, WHO along with other partners and affiliated organizations is taking joint actions to combat 2019-nCOV.

4.5. A decline in World Tourism: World travel industry that accounts for $10.4 \%$ and $10 \%$ of world GDP and employment respectively has been greatly affected by the spillover effect of treacherous coronavirus crisis (weforum 2020b). World Tourist Organization (UNWTO) inspires at 'Stay home, travel tomorrow' and upholds the importance of joint responsibility of travelers and the tourism sector. It also expects that there will be $20 \%$ to $30 \%$ fall in world tourist arrivals concerning 2019 figures which is equivalent to $\$ 300-450$ billion (UNWTO 2020) that will make millions of tourism jobs cut and 4.5\% GDP loss is estimated in OECD countries along with a drop of $7 \%$ of employment (OECD 2020b).

4.6. Policy actions to combat COVID-19: In the time of emergencies, it is not possible to prescribe proper policy guidelines to address this problem. However, various international and regional organizations as part of a greater community have come forward with their expertise and supports. With the elapse of time, more support is being declared to realizing its predatory nature. The different kind of responses from the world perspective to tackle the COVID-19 is summarized in annex table 1.

Table 1. Summary of rapid responses to tackle COVID-19.

\begin{tabular}{|l|ll|}
\hline \multicolumn{1}{|c|}{ Name of organization } & \multicolumn{1}{c|}{ Responses tackle to COVID-19 } \\
\hline $\begin{array}{l}\text { UN } \\
\text { (United Nations) }\end{array}$ & $\bullet \begin{array}{l}\text { Working together with global experts, governments and partners } \\
\text { Freed the US \$15 million from the Central Emergency Response Fund } \\
\text { (CERF) to help vulnerable countries. }\end{array}$ \\
\hline $\begin{array}{l}\text { WHO } \\
\text { (World Health Organization) }\end{array}$ & $\begin{array}{l}\text { Awareness-raising programs through online platforms such as advice } \\
\text { for the public, situation reports, media resource, technical guidance, } \\
\text { travel advice, Donor and partners, Training and exercise and making } \\
\text { solidarity response firm. }\end{array}$ \\
\hline
\end{tabular}

\footnotetext{
${ }^{1} \mathrm{Mb} / \mathrm{d}$ : Million Barrels Per Day.

${ }^{2} \mathrm{~kb} / \mathrm{d}$ : Thousand Barrels Per Day.
} 


\begin{tabular}{|c|c|}
\hline Name of organization & Responses tackle to COVID-19 \\
\hline $\begin{array}{l}\text { ILO } \\
\text { (International } \\
\text { Organization) }\end{array}$ & $\begin{array}{l}\text { - Formulating policies of four key pillars to fight COVID-19 based on } \\
\text { International Labor Standards. }\end{array}$ \\
\hline $\begin{array}{lr}\text { UNESCO } & \\
\text { (United Nations Educational, } \\
\text { Scientific } \\
\text { Cultural Organization) }\end{array}$ & $\begin{array}{l}\text { - Supporting governments for distance learning, open science, } \\
\text { knowledge and culture sharing, as fundamental means to stand } \\
\text { together and tighten the bonds of our shared humanity. }\end{array}$ \\
\hline $\begin{array}{l}\text { UNIDO } \\
\text { (United Nations Industrial } \\
\text { Development Organization) }\end{array}$ & $\begin{array}{l}\text { - Responding to the COVID-19 crisis by advising on how to mitigate } \\
\text { the impact of the disruption of productive activities and on reactivating } \\
\text { production and supply chains along with development support in the } \\
\text { recovery phase. }\end{array}$ \\
\hline $\begin{array}{l}\text { ICAO } \\
\text { (International Civil Aviation } \\
\text { Organization) }\end{array}$ & $\begin{array}{l}\text { - Working closely with governments and industry partners such as the } \\
\text { International Air Transport Association (IATA) and Airports Council } \\
\text { International (ACI) to protect the health of travelers and reduce the } \\
\text { risk of transmission. }\end{array}$ \\
\hline $\begin{array}{l}\text { IMO } \\
\text { (International } \\
\text { Organization) }\end{array}$ & $\begin{array}{l}\text { - Calling on the government to protect public health and address } \\
\text { COVID-19, without introducing obstacles to ship and port operations, } \\
\text { including the movement of seafarers and marine personnel. }\end{array}$ \\
\hline $\begin{array}{l}\text { WMO } \\
\text { (World } \\
\text { Organization) }\end{array}$ & $\begin{array}{l}\text { - Paying tribute to the } \mathrm{w} \\
\text { forefront of the COVID } \\
\text { partner organizations. }\end{array}$ \\
\hline $\begin{array}{l}\text { ITU } \\
\text { (International } \\
\text { Telecommunications Union) }\end{array}$ & $\begin{array}{l}\text { L } \\
\text { er } \\
\text { ay }\end{array}$ \\
\hline $\begin{array}{l}\text { IFAD } \\
\text { (International } \quad \text { Fund } \\
\text { Agricultural Development) }\end{array}$ & $\begin{array}{l}\text { - Adapting and building rural people's } \\
\text { projects, operating across } 60 \text { coun } \\
\text { efficient, healthy development. }\end{array}$ \\
\hline $\begin{array}{l}\text { IMF } \\
\text { (International Monetary Fund) }\end{array}$ & - Released $\$ 50$ Billion to tackle Corona \\
\hline $\begin{array}{l}\text { WORLD BANK GROUP } \\
\text { BRD: International Bank for } \\
\text { Reconstruction and Development } \\
\text { IDA: International Development } \\
\text { Association } \\
\text { IFC: International Finance } \\
\text { Corporation }\end{array}$ & $\begin{array}{l}\text { - Released } \$ 14 \text { billion packages to prevent the rapid spread of COVID- } \\
19 \text { in association with WB and IFC. } \\
\text { Launched first operations for COVID-19 (coronavirus) emergency } \\
\text { health support, strengthening developing country responses. } \\
\text { - } \$ 160 \text { billion over the next } 15 \text { months would disburse as part of the } \\
\text { boarder economic program. }\end{array}$ \\
\hline $\begin{array}{l}\text { ADB } \\
\text { (Asian Development Bank) }\end{array}$ & $\begin{array}{l}\text { ced the US } \$ 6.5 \text { as the initial response to COVID-19 } \\
\text { ic. }\end{array}$ \\
\hline $\begin{array}{l}\text { IDB } \\
\text { (Islamic Development Bank) }\end{array}$ & - Allocates US \$2.3 Billion to Member Countries for the pandemic. \\
\hline $\begin{array}{l}\text { AIIB } \\
\text { (Asian Infrastructure Investment } \\
\text { Bank) }\end{array}$ & billion for COVID-19 recovery. \\
\hline $\begin{array}{l}\text { weforum } \\
\text { (World Economic Forum) }\end{array}$ & $\begin{array}{l}\text { - Galvanizing the global business community for collective action. } \\
\text { - Protecting people's livelihoods and facilitate business continuity. } \\
\text { - Mobilizing cooperation and business support for the COVID-19 } \\
\text { response. }\end{array}$ \\
\hline
\end{tabular}

Source: Summarized by the author from the official website of the respective organization (as of 2020, April 15).

Therefore, it can be expected that if all the stakeholders of regional and international sides in collaboration with national authorities take proper, devoted and detailed plan to tackle this sudden and unexpected situation, the success will come within the shortest possible time

5. Probable Impact of coronavirus on Bangladesh economy: The analyses of the impact of coronavirus on Bangladesh may be divided into two parts, namely, (I) Impact on the domestic economy of Bangladesh and (II) Impact on the external economy of Bangladesh.

5.1. Impact on Domestic Economy: The impact on the domestic economy depends on the spread of the virus and the duration of the lockdown and quarantine of the people. The general holidays extended up to 25 April 2020 in 
three consecutive declarations. This economic inactivity of the people may lead to an adverse effect on the goods and money markets of the country. The nature and depth of the consequences are described as follows-

5.1.1. Effect on GDP Growth, Government Expenditure and Investment: Bangladesh has achieved sustainable growth of more than 6 percent on average during the last decade. Now, GDP growth is accelerating gradually. According to the Bangladesh Bureau of Statistics (BBS), GDP growth surpassed 7\% in FY2015-16 and stood at $7.11 \%$, afterward GDP growth increased to $7.28 \%$ in FY2016-17 and 7.86 \% in FY2017-18.

Table 2. Overall Scenario in GDP Growth, Government Expenditure and Investment

Taka in crore

\begin{tabular}{|l|l|l|}
\hline Year & \multicolumn{1}{|c|}{ FY2018-19 } & \multicolumn{1}{|c|}{ FY2019-20 (Projected) } \\
\hline GDP at Current Price & $2,54,2484$ & $2,88,5872$ \\
\hline GDP Growth rate & $8.15 \%$ & $8.20 \%$ \\
\hline $\begin{array}{l}\text { Total Investments as \% of GDP at } \\
\text { Current price }\end{array}$ & $31.57 \%$ & $32.80 \%$ \\
\hline Total Expenditure & $4,42,541$ & $5,23,190(18.1 \%$ of (GDP) \\
\hline Budget Deficit & $1,25,929$ & $1,45,380(-5 \%$ of GDP) \\
\hline Total Tax Revenue & $2,89,600$ & $3,40,100$ \\
\hline Of which NBR Tax Revenue & $2,80,000$ & $3,25,600$ \\
\hline $\begin{array}{l}\text { Annual Development Program } \\
\text { (ADP) }\end{array}$ & $1,67,000$ & $2,02,721$ \\
\hline
\end{tabular}

Source: $\mathrm{BBS}^{1}, \mathrm{MoF}^{2}$

As the above table 2. implies Bangladesh has achieved a high growth rate in GDP of 8.15\% in FY2018-19 with a total investment of $31.57 \%$ of total GDP. For FY2019-20, the government has proposed a budget of Tk $5,23,190$ Crore with an expected GDP growth rate of $8.2 \%$. Targeted investment is $32.8 \%$ of the total GDP with the Annual Development Program (ADP) of Tk 2,02,721 crore. Besides, the targeted budget deficit is 1,45,380 crore Tk which is $5 \%$ of total GDP.

The expected revenue collection for FY2019-20 is Tk.3,40,100 crore of which major portion will be collected by NBR (National Board of Revenue) amounting to Tk. 3,25,600 Crore. In the period July-December, 2019, the target was to collect Tk.1,36,668.98 Crore but actually, only Tk.1,05,161.35 crore $(76.95 \%$ of the total target up to December,2019) was collected by NBR (National Board of Revenue 2020). Not only NBR tax revenue but also other sources of taxes and revenues can be highly affected due to uncertain situations in business activities.

Overall Production in the domestic economy may be highly harmed due to the sudden attack of Coronavirus. This situation is totally different from other economic downturns rather it's a health-related issue concerning life and death. So, production may decrease due to a lack of confidence to make a profit among producers in this uncertain situation. Another reason for hampering production is the shortage of capital goods and machinery that need to be imported from other countries. The import of those capital goods will decrease if the overall situation in the world is not improved. Subsequently, labor demand may fall gradually and so it will create a huge number of unemployed laborers. Eventually, that will result in the low level of income and purchasing power of the households in the economy. In this situation, if government plans for fiscal expansion, that will evidently increase government expenditure more than the target.

It is known that investment mostly depends on the interest rate. But even lower interest rates may not increase investment due to other exogenous factors caused by virus diseases like lack of confidence to make a profit among investors, unhealthy working environment, fear of spreading disease, etc.

Due to the COVID-19 pandemic, World Bank is anticipating that the GDP growth rate for Bangladesh will be within 2-3\% in the FY2019-20 (World Bank 2020b). Though the government has taken some fiscal measures, it is doubted that expectation of high growth rate, investment and budget plan may not be properly and timely implemented due to current and future economic crises.

5.1.2. Effect on money, interest rate and inflation: To find the overall view of the domestic economy, money, interest rate and inflation level should be considered. Broad money growth is one of the instruments to accommodate targeted GDP growth and inflation within a range. To analyze the impact on money, the present scenario of Broad money stock and its comparison with the monetary policy for FY2019-20 should be perceived. In the proposed monetary policy for FY2019-20, broad money growth is set to $12.5 \%$ by the end of June 2020 and $11.3 \%$ by the end of December 2019 (Bangladesh Bank 2019a). After the end of December 2019, broad money (M2) grew by $12.04 \%$ compared to December 2018 which is above the target level of $11.30 \%$. It indicates a very well liquidity position in the economy.

\footnotetext{
${ }^{1}$ BBS: Bangladesh Bureau of Statistics

${ }^{2}$ MoF: Ministry of Finance
} 
Table 3. Comparative Analysis of Monetary and Credit flow in Bangladesh.

\begin{tabular}{|c|c|c|c|}
\hline Item & Period & December, 2018 & December, 2019 \\
\hline \multirow{3}{*}{$\begin{array}{l}\text { Broad Money } \\
\text { (Outstanding Stock) }\end{array}$} & Taka in crore & 1155360.7 & 1294435.1 \\
\hline & Actual Growth & & $12.04 \%$ \\
\hline & $\begin{array}{l}\text { Target Growth in Monetary Policy 2019- } \\
20 \text { (Up to December, 2019) }\end{array}$ & & $11.30 \%$ \\
\hline \multirow{3}{*}{$\begin{array}{l}\text { Total Domestic Credit } \\
\text { (Outstanding Stock) }\end{array}$} & Taka in crore & 1080350.0 & 1240598.1 \\
\hline & Actual Growth & & $14.83 \%$ \\
\hline & $\begin{array}{l}\text { Target Growth in Monetary Policy 2019- } \\
20 \text { (Up to December, 2019) }\end{array}$ & & $14.50 \%$ \\
\hline \multirow{3}{*}{$\begin{array}{l}\text { Credit to Public Sector } \\
\text { (Outstanding Stock) }\end{array}$} & Taka in crore & 121498.8 & 187446.5 \\
\hline & Actual Growth & & $54.28 \%$ \\
\hline & $\begin{array}{l}\text { Target Growth in Monetary Policy 2019- } \\
20 \text { (Up to December, 2019) }\end{array}$ & & $25.20 \%$ \\
\hline \multirow{3}{*}{$\begin{array}{l}\text { Credit to Private Sector } \\
\text { (Outstanding Stock) }\end{array}$} & Taka in crore & 958851.2 & 1053151.6 \\
\hline & Actual Growth & & $9.83 \%$ \\
\hline & $\begin{array}{l}\text { Target Growth in Monetary Policy 2019- } \\
20 \text { (Up to December, 2019) }\end{array}$ & & $13.20 \%$ \\
\hline
\end{tabular}

Source: Monthly Economic Trends-March, 2020; Bangladesh Bank

A surge in government borrowings is the main reason that increased broad money (M2) growth to $12.04 \%$. Here, in the above table 3 . shows overall domestic credit increased by $14.83 \%$, higher than the targeted growth of $14.5 \%$ up to December 2019. That increase in domestic credit is mainly due to the increase of credit flow to the public sector by $54.28 \%$ which is too much higher than the target growth of $25.20 \%$. On the contrary, private sector credit grew by only $9.83 \%$, much lower than the targeted growth of $13.20 \%$ in December 2019 . Higher growth of public sector credit shrinks the sources of credit to the private sector. The main reason for this high percentage of growth is the deficit financing of government from the banking sector because of lower-than-targeted growth of government revenue. To pull up the economy from this adverse situation, it can be said that the government will increase expenditure for different types of economic incentives and that will further increase government borrowings. In an extreme situation, Central bank may have to print money to support the government. But in that case, the government should consider the fact that the economy may suffer from a high level of inflation. Table 4. Comparison of Rate of Inflation and Interest rate

\begin{tabular}{|l|l|l|l|l|l|l|}
\hline & \multicolumn{3}{|c|}{$\begin{array}{r}\text { Rate of interest of Scheduled Banks } \\
\text { (Weighted Average) }\end{array}$} & \multicolumn{2}{c|}{$\begin{array}{c}\text { Rate of Inflation Measured by Consumer } \\
\text { Price Index Point to point (Base: 2005- } \\
\text { 06=100) }\end{array}$} \\
\hline Period & Deposits & Advances & Spread & General & Food & Non-Food \\
\hline January,2019 & 5.34 & 9.49 & 4.15 & 5.42 & 5.33 & 5.57 \\
\hline January,2020 & 5.69 & 9.66 & 3.97 & 5.57 & 5.12 & 6.30 \\
\hline
\end{tabular}

Source: BBS \& Monthly Economic Trends-March, 2020; Bangladesh Bank

Table 4. shows the rate of interest of scheduled banks (Weighted average) for January 2019 and January 2020. Both borrowing rates and lending rates are increased in January 2020 compared to January 2019. But the spread is slightly decreased to 3.97 in January 2020. Recently, BB has fixed the lending interest rate to 9\% (Bangladesh Bank 2020b) which was previously varied above $9 \%$ from bank to bank. As the lending rate is fixed at $9 \%$, to maintain spread at least a $3 \%$ borrowing interest rate will be within a maximum of $5 \%$ to $6 \%$.

This low interest and low income during the economic crisis, individuals will start withdrawing their savings. Moreover, this low borrowing interest rate will encourage individuals to shift their investment or fund from the banking sector to another sector. But given the uncertainty, individuals may not invest rather they may tend to hold more money in hand for facing any difficulty. Further, this precautionary motive of individuals for unexpected health issues will increase money demand. An increase in money demand will lead to lower stocks of loanable funds in financial institutions.

On the other side, Central bank has already taken an initiative to increase the liquidity by decreasing Cash Reserve Ratio (CRR) rate to 4\% from 5.5\% as of April 2018 on a bi-weekly average basis ("Bangladesh Bank," 2020c) and repo interest rate to 5.25\% from 6\% as of April 2018 ("Bangladesh Bank," 2020d).

The point to point general inflation increased to $5.57 \%$ in January 2020 from $5.42 \%$ in January 2019 which was slightly higher than the target of 5.50\% for FY2019-20. Above table 4. further shows in January 2020 food inflation is $5.12 \%$ and Non-food inflation is $6.30 \%$. As the government is essentially starting monetary expansion, there will be a threat of inflation in the economy. Nonetheless, the supply side of the economy should also be considered by the government to control the inflation level within a certain range.

The total effects of the virus in the domestic economy of Bangladesh can be summarized by following figure 
1.
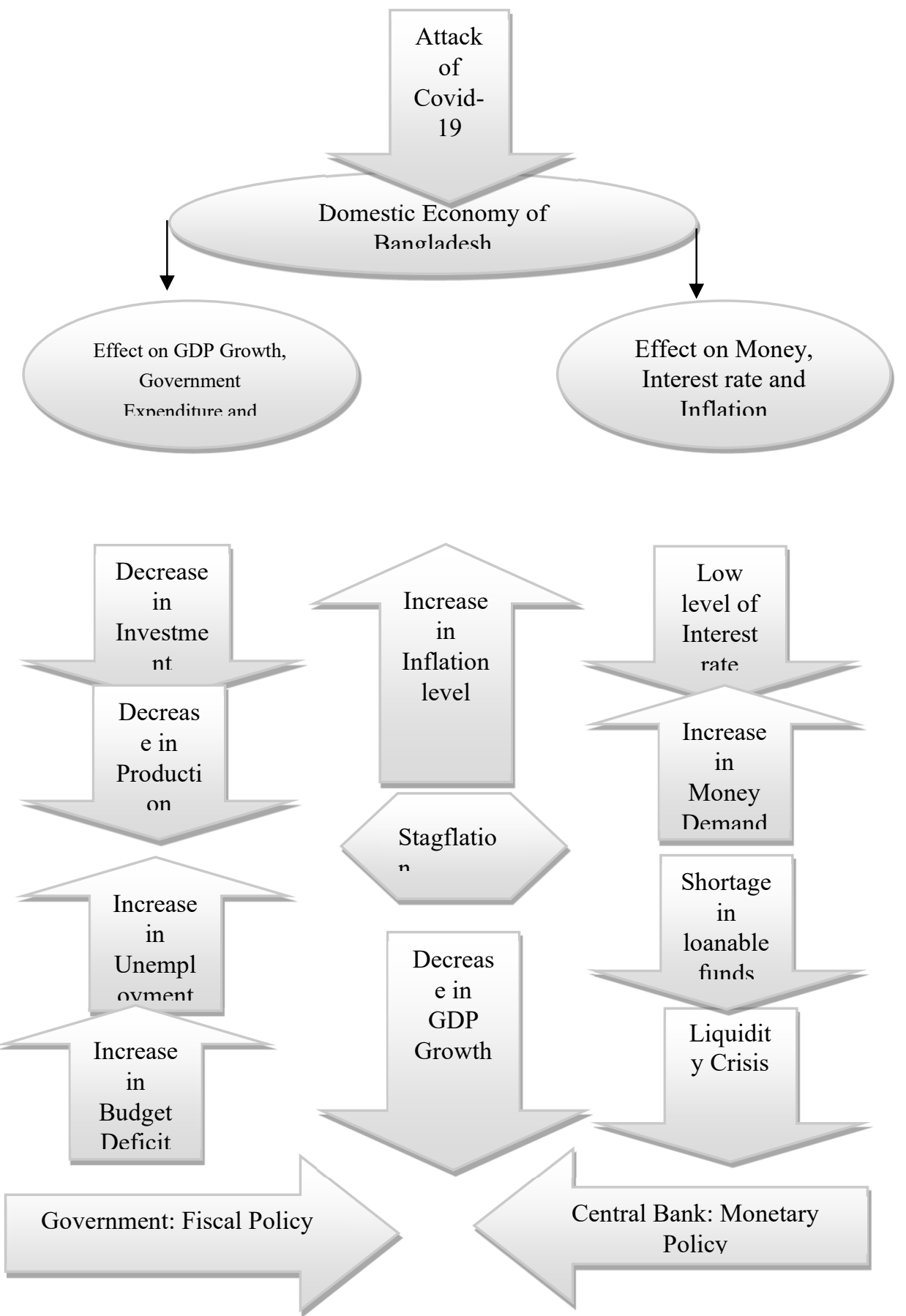

Figure 1. Overview of effect on Domestic Economy of Bangladesh

In this figure, it can be seen that how different macroeconomic variables of the domestic economy of Bangladesh may affect the epidemic situation. Here, the domestic economy is divided into two parts- (I) effect on GDP growth, government expenditure and investment and (II) effect on money, interest rate and inflation. Due to the virus attack, investment as well as production may be decreased with a huge number of unemployed labor and large government budget deficit. On the contrary, as the government has taken initiative to lower the interest rate that will increase money demand and accordingly the economy may face a liquidity crisis. Thus, the economy may experience low GDP growth with high inflation i.e. stagflation. Finally, both government and central bank have to take different monetary and fiscal initiatives to recuperate the economy.

5.2 Effect on External economies: The external economy of Bangladesh is mainly comprised of import, export and wage remittance. Bangladesh mainly depends on China and India for importing raw materials and machinery. On the other side, Bangladesh is one of the largest apparel exporters in the world. Besides, jute goods, home textile 
and footwear are also an emerging sector for export at present. Wage remittance is another important contributor to the Bangladesh economy. Around the US \$16 Billion was remitted to Bangladesh in FY 2018-19 (Bangladesh Bank 2020e). The Table-5 below describes the present scenario of import, export, wage remittance and current account balance in Bangladesh.

Table 5. Present scenario of Import, Export, Wage Remittance and Current Account Balance.

\begin{tabular}{|c|c|c|c|c|c|c|c|c|}
\hline & & & & & & & & Taka in c1 \\
\hline Item & & Import & & & Export & & Wage & $\begin{array}{c}\text { Current } \\
\text { Account }\end{array}$ \\
\hline Year & $2019-20^{\mathrm{P}}$ & 2018-19 & $\begin{array}{l}\% \text { change } \\
\text { Compared } \\
\text { to } 2018-19\end{array}$ & $2019-20^{P}$ & 2018-19 & $\begin{array}{c}\% \text { change } \\
\text { Compared } \\
\text { to } 2018- \\
19\end{array}$ & $2019-20$ & $2019-20^{\mathrm{P}}$ \\
\hline July & 38296 & 38264 & $0.08 \%$ & 27982 & 26497 & $5.60 \%$ & 13500.42 & 319.8 \\
\hline August & 32831 & 33204 & $-1.12 \%$ & 22292 & 21532 & $3.53 \%$ & 12208.14 & 57.7 \\
\hline September & 35682 & 39794 & $-10.33 \%$ & 26020 & 25155 & $3.44 \%$ & 12479.89 & -7727.7 \\
\hline October & 42590 & 42633 & $-0.10 \%$ & 25598 & 25315 & $1.12 \%$ & 13900.05 & -5968.0 \\
\hline November & 33798 & 37414 & $-9.66 \%$ & 23276 & 22567 & $3.14 \%$ & 13185.40 & 747.0 \\
\hline December & 39452 & 37823 & $4.31 \%$ & 25074 & 22833 & $9.81 \%$ & 14362.09 & -2112.3 \\
\hline Januar & 40005 & 46530 & $-14.02 \%$ & 26438 & 27193 & $-2.78 \%$ & 13910.27 & \\
\hline
\end{tabular}

Source: Monthly Economic Trends-March, 2020; Bangladesh Bank; P: Provisional

5.2.1. Effect on Import and Export: Import has already been declining relentlessly during FY2019-20 compared to previous almost in every month except December 2019. Moreover, China is the largest source of import for Bangladesh which occupies around $26 \%$ of total imports of the country (Bangladesh Bank 2019f). As China is adversely affected so there will be a further reduction of overall imports. Another reason that may reduce import is the shortage of overall aggregate demand caused by the bad economic situation. Condition of export earning is well enough in the FY2019-20 compared to FY2018-19 up to December 2019. But in January it is 2.78\% less than that of the previous fiscal year.

According to recent news, export orders have already been canceled due to the present severe unpleasant impact of coronavirus in the European Union (EU) countries as they are major trading partners for Bangladesh. If the world cannot control the pandemic, this will worsen the situation in the future when more orders will be canceled (Ishty 2020).

5.2.2. Impact on Wage Remittance: Remittance is another vital element for the economy. So far, remittance is received amounting to USD 1.45 billion in February 2020 which is the lowest in the last five months (Bangladesh Bank 2020g). Giving a 2\% cash incentive from July 2019, wage remittance has increased 20\% in the FY2019-20 up to February 2020 compared to FY2018-19. Kingdom of Saudi Arabia (KSA), United Arab Emirates (UAE) and United States of America (USA) are the top three source countries of wage remittance for Bangladesh shown in (table 6). Besides, some of the Middle East Asian countries like Kuwait, Oman, Qatar, and Bahrain are also important markets for Bangladeshi expatriates ("Bangladesh Bank," 2020h). But presently, most of the Middle East and European Union countries including the USA, are facing locked down and quarantine due to this infectious disease. If this lockdown continues for a longer period then the economic system will be collapsed that will bring about huge unemployed laborers with no opportunities. Many expatriates will have to return home with an empty hand. As a result, it can be feared that the inflow of wage earners' remittance may be hampered massively. Table 6. Major Country-wise Wage Earner's Remittance.

\begin{tabular}{|c|c|c|c|}
\hline \multicolumn{3}{|c|}{ FY2019-20 } \\
\hline Country & Taka in crore) \\
\hline KSA (Kingdom of Saudi Arabia) & December & January & February \\
\hline USA (United States of America) & 2850.29 & 2726.99 & 2621.11 \\
\hline UAE (United Arab Emirates) & 1762.32 & 1894.80 & 1764.31 \\
\hline
\end{tabular}

Source: Monthly Economic Trends-March, 2020; Bangladesh Bank

5.2.3. Impact on Balance of Payment: Table 5. shows the Current account balance is seen positive in July, August, and November and found negative in September, October and December 2019. According to Bangladesh Bank website (Bangladesh Bank 2020i) overall provisional balance of payment position for July to January 2020 is positive and amounting 132 Million USD. But for the global economic crisis, if export receipts and wage remittance remain low, this will put pressure on the overall balance of payment position. In this regard, the impact of the global financial crisis in 2008 on Bangladesh can be considered. Ali and et al. (2011) have shown that Bangladesh showed remarkable resilience and took the international business advantage as the global economy 
begins to recover. They also added that one of the reasons of not decreasing export is the types of commodities that Bangladesh export is low priced consumer goods and have inelastic demand. Islam et al. (2013) stated that Bangladesh has shown positive figures in the RMG sector even in the bad days of the economic situation. So even in this present global epidemic situation, when the global economy will begin to improve, Bangladesh can take the benefit of international trade for this specific export pattern. But the most important precondition to take international benefit is the sound and secured health situation in the country. Global oil prices can also help to improve the balance in the short term because the oil price is already lower than the previous year (OPEC 2020) and it may not increase overnight due to the present world economic situation. Therefore, it can be expected that the overall BOP position will not worsen within the coming months. The following figure 2 . summarizes the external dynamics of Bangladesh due to the COVID-19 attack.

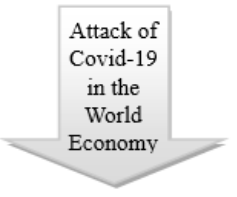

External Economy of Bangladesh

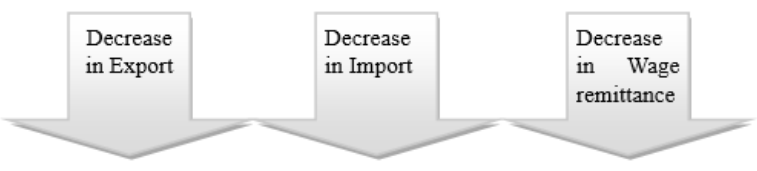

Balance of Payment

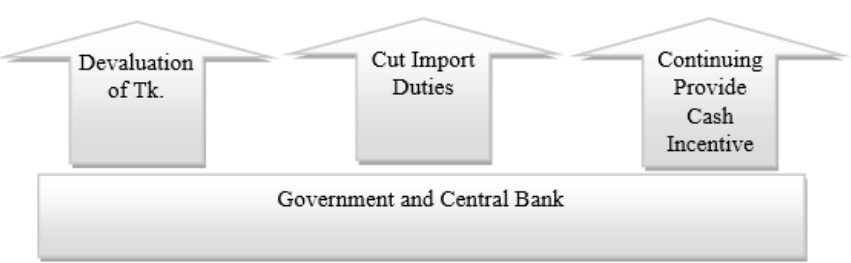

Figure 2. Overview of effect on External Economy of Bangladesh

In this figure 2. above, it is summarized that how the external economy can be affected due to coronavirus. It can be feared that all export, import and wage remittance can be declined. For this, the government and central bank can take actions like exchange rate control, cut import duties or provide cash incentives to support the balance of payment position.

6. Measures to tackle the effect of Coronavirus: In the time of this emergency need and as an immediate response, the government of Bangladesh came up with many stimuli and incentive packages for the revival of the economy and the survival of marginalized poverty-ridden people. Besides, several policies are being formed and prescribed to fight this shock.

6.1. Incentive packages and future recovery: The number of packages and their amount are being gradually improved and improvised with the realization of the severity of the problem. Additionally, the number of social safety net programs are being expanded thoroughly for the betterment of the country and its economy. The following table 7 . Shows the summary of stimulus packages provided by the government of Bangladesh. 
Table 7. Summary of incentive package by Bangladesh Government

\begin{tabular}{|c|c|c|}
\hline Amount & Incentivized Sector & Comments \\
\hline Tk.250 Crore & Allocation for Health care service & $\begin{array}{l}\text { Emergency package released by the finance } \\
\text { minister in two installments }\end{array}$ \\
\hline Tk.5,000 crore & $\begin{array}{l}\text { Paying salaries and allowances of } \\
\text { export-oriented industries workers and } \\
\text { employees }\end{array}$ & Emergency package \\
\hline Tk.30,000 crore & $\begin{array}{l}\text { To affected industries and service } \\
\text { sector organizations as working } \\
\text { capital, } \\
\text { through banks as a low-interest loan }\end{array}$ & $\begin{array}{l}\text { Total Lending interest rate }=9 \% \\
\text { Payment by business org. }=4.5 \% \\
\text { Payment by Government }=4.5 \% \text { (as subsidy) }\end{array}$ \\
\hline Tk.20,000 crore & $\begin{array}{l}\text { As working capital of small and } \\
\text { medium enterprises (SMEs) including } \\
\text { cottage industries }\end{array}$ & $\begin{array}{l}\text { Total Lending rate }=9 \% \\
\text { Payment by business org. }=4 \% \\
\text { Payment by Government }=5 \% \text { (as subsidy) }\end{array}$ \\
\hline Tk.12,750 crore & $\begin{array}{l}\text { For enhancing export Development } \\
\text { Fund or EDF size to facilitate raw } \\
\text { materials imports under back-to-back } \\
\text { LC. }\end{array}$ & $\begin{array}{l}\text { Payment of interest rate }=2 \% \text { (From presently } \\
2.73 \% \text { in line with current London Interbank } \\
\text { Offered Rate-LIBOR }+1.5 \% \text { ) }\end{array}$ \\
\hline Tk.5,000 crore & $\begin{array}{l}\text { Introduction of new credit facility by } \\
\text { Central Bank titled 'Pre-shipment } \\
\text { Credit } \\
\text { Refinance Scheme' }\end{array}$ & Payment of interest $=7 \%$ \\
\hline Tk.5,000 crore & $\begin{array}{l}\text { To pump running capital into the } \\
\text { agriculture, fisheries, poultry and dairy } \\
\text { sectors. }\end{array}$ & Farmers' payment of interest rate $=5 \%$ \\
\hline Tk.750 crores & $\begin{array}{l}\text { For civil and army officials, police and } \\
\text { health workers engaged in tackling the } \\
\text { crisis. }\end{array}$ & For Health and insurance policies. \\
\hline Tk.100 crore & For doctors, nurses, health workers & $\begin{array}{l}\text { - As a reward for their dedication and } \\
\text { bravery work. }\end{array}$ \\
\hline Tk.760 crore & $\begin{array}{l}\text { For informal sector workers facing } \\
\text { unemployment during general holiday }\end{array}$ & - As part of assistance. \\
\hline $\begin{array}{l}\text { Special incentive } \\
\text { allowance (Equal to } \\
\text { basic salary) }\end{array}$ & $\begin{array}{l}\text { For Bankers working at their banks } \\
\text { during the lockdown period for } \\
\text { coronavirus outbreak. }\end{array}$ & $\begin{array}{l}\text { - An equal of basic salaries for working for } \\
\text { a minimum of } 10 \text { days in the general } \\
\text { holidays. } \\
65 \% \text { of their basic salaries, ranging the } \\
\text { amount between Tk30,000 and } \\
\text { Tk100,000 for temporary or contractual } \\
\text { officers and employees. }\end{array}$ \\
\hline
\end{tabular}

Source: Summarized by the author from different national newspapers.

Various experts and different policy thinkers questioned the source of money, time, condition, quantity and sectors of priority of incentivization as a part of their scrutinization. It is also recognized that the benefit of the packages should be reached to the targeted people and sectors with a politically feasible and corruption-free government with transparency, accountability for the persistence of sustainability and viability. Besides, these immediate responses should be matched with a budget of FY2020-21, the eighth five-year plan, LDC graduation, and other mid and long-term plans. All measures should be sketched in such a coordinated way that we can have economically positive Bangladesh.

6.2. Policy Recommendation: To stimulate the economy, the government should take both fiscal and monetary measures. Policies will be more effective if fiscal and monetary policy is well coordinated. Besides,

1. Before anything, the government should control the outbreak of Coronavirus in the economy by any means. Because the epidemic continues for the large time then policies and measures cannot play any effective role to recover the economy. So, the government should allocate funds as much as the health sector needs.

2. The government should provide incentives to producers especially those who are involved in MicroSmall and Medium Enterprises (MSMEs) for continuing their production under any circumstances.

3. The agriculture sector should be given topmost priority in this situation. The government should ensure the appropriate price level for the agricultural product to protect the farmers under this economic crisis. 
The government can also give subsidies to the farmers for buying agricultural machinery to harvest crops at a low cost.

4. The central bank has already decreased policy rates (i.e. CRR, Repo Rate) to increase the money supply. If Central Bank wants to go further monetary easing, it may buy different government bills and bonds held by commercial banks.

5. To facilitate investment, a reduction in lending interest rate is the common practice. But in this situation, lending and borrowing interest rate should not be lowered than the present, because, it will put pressure on financial institutions to run their business. Moreover, the low lending interest rate may result in an increase in non-performing loans (NPL) in the economy. So, to increase investment, other fiscal and monetary measures can be taken in to consideration.

6. The government may lower the tax level at different sources to support investors, firms and companies during this economic meltdown. The government may also cut import duties in essential commodities to control the inflationary pressure in the economy.

7. To promote export diversification, the government should give special supports to exporters, other than the RMG sectors.

8. The government may consider the devaluation of TK against US Dollar to increase the competitiveness of exporters in the world market and

9. The government proposed a $2 \%$ cash incentive for the expatriate from FY2019-20, to encourage more foreign remittance into the country, the government may continue this incentive and allocate budget for the next fiscal year also.

7. Conclusion: There may be enormous unpredictable and multi-dimensional economic damages due to the rapid and lethal spread of COVID-19 throughout the world. This haphazard uncontrollable situation can only be addressed nationally and internationally if both stakeholders act wisely with precise and problem-oriented policy actions with the proper joint coordination and plans. At last, it is mandatory to mention that human resources are the key factor for the revival of the economy of any country affected by this disease. Therefore, keeping them fit for the future work social awareness and proper implementation of government social safety net programs without any leakages in this emergency moment can make a huge difference. We can surely hope that the world will again rejoice by conquering such a type of invincible disease.

\section{References}

Asian Development Bank 2020a, The Economic Impact of the COVID-19 Outbreak on Developing Asia, viewed 10 April 2020,< https:/www.adb.org/sites/default/files/publication/571536/adb-brief-128-economic-impactcovid19-developing-asia.pdf $>$

Asian Development Bank 2020b, Developing Asia Growth to Fall in 2020 on COVID-19 Impact, viewed 10 April, < https://www.adb.org/news/developing-asia-growth-fall-2020-covid-19-impact $>$

Ali, M. M., Islam, A. M., \& Wise, V. J. 2011, 'The Great Recession of 2008: Impact on the Bangladeshi economy and international business implications', Thunderbird International Business review, vol. 53(2), pp. 263-276, DOI: $10.1002 /$ tie.20405.

Ayittey, F. K., Ayittey, M. K., Chiwero, N. B., Kamasah, J. S. \& Dzuvor, C. 2020, 'Economic impacts of Wuhan 2019-nCoV on China and the world', Journal of Medical Virology, vol. 92, pp. 473-475, DOI: 10.1002/jmv.25706.

Bangladesh Bank (BB) 2020, Monthly Economic Trends March 2020, Bangladesh Bank, viewed 9 April 2020,< https://www.bb.org.bd/pub/monthly/econtrds/mar20/econtrds.php>

Bangladesh Bank (BB) 2019a, Monetary Policy Statement Fiscal Year 2019-20, Bangladesh Bank, viewed 9 April 2020,< https:/www.bb.org.bd/monetaryactivity/mps/mps.php>

Bangladesh Bank (BB) 2020b, BRPD Circular No. 03: Rationalization of Rate of Interest/Profit on Lending/Investment, $\quad$ Bangladesh Bank, $\quad$ viewed $12 \quad$ April 2020, $<$ https://www.bb.org.bd/mediaroom/circulars/brpd/feb242020brpd03.pdf>

Bangladesh Bank (BB) 2020c, MPD Circular No. 03: Change of Cash Reserve Ratio (CRR), Bangladesh Bank, viewed 14 April 2020,<https://www.bb.org.bd/mediaroom/circulars/mpd/apr092020mpd03.pdf>

Bangladesh Bank (BB) 2020d, MPD Circular No. 04: Re-fixation of Repo interest rate of Bangladesh Bank, Bangladesh Bank, $\quad$ viewed $14 \quad$ April $<$ https://www.bb.org.bd/mediaroom/circulars/mpd/apr092020mpd04.pdf $>$

Bangladesh Bank (BB) 2019e, Yearly data of Wage earner's remittance, Bangladesh Bank, viewed 13 April 2020 , $<$ https://www.bb.org.bd/econdata/wageremitance.php $>$

Bangladesh Bank (BB) 2019f, Imports-Major country/commodity-wise import payments (Yearly), Bangladesh Bank, viewed 12 April 2020, < https://www.bb.org.bd/econdata/index.php >

Bangladesh Bank (BB) 2020g, Monthly data of Wage earner's remittance inflow, Bangladesh Bank, viewed 13 
April 2020, <https://www.bb.org.bd/econdata/wageremitance.php>

Bangladesh Bank (BB) 2020h, Wage Earners' Remittance Inflows: Top 30 Countries Received, Bangladesh Bank, viewed 13 April 2020, <https://www.bb.org.bd/econdata/wageremitance.php>

Bangladesh Bank (BB) 2020i, Balance of Payments (Monthly data), Bangladesh Bank, viewed 12 April 2020, $<$ https://www.bb.org.bd/econdata/wageremitance.php $>$

Bangladesh Bureau of Statistics (BBS) 2019, Gross Domestic Product of Bangladesh 2018-19(F), Bangladesh Bureau of Statistics, viewed 9 April 2020, <http://www.bbs.gov.bd/site/page/dc2bc6ce-7080-48b3-9a04$73 \mathrm{cec} 782 \mathrm{~d} 0 \mathrm{df} /->$

Bangladesh Bureau of Statistics (BBS) 2020, Consumer Price Index (CPI), Inflation Rate and Wage Rate Index (WRI) in Bangladesh, March 2020, Bangladesh Bureau of Statistics, viewed 9 April 2020, $<$ http://bbs.portal.gov.bd/sites/default/files/files/bbs.portal.gov.bd/page/9ead9eb1_91ac_4998_a1a3_a5caf4 ddc4c6/2020-03-25-17-16-1b1f9c31b5e39455cd94032df757517d.pdf $>$

NBC News 2020, 'Coronavirus crash wipes \$5 trillion off world stocks', NBC News, 28 February, viewed 13 April $2020,<\mathrm{https}: / / \mathrm{www} . n b c n e w s . c o m /$ business/markets/coronavirus-crash-wipes-5-trillion-world-stocksn1144636>

International Energy Agency (IEA) 2020, Oil Market Report-March 2020, International Energy Agency (IEA), viewed 14 April 2020, <https:/www.iea.org/reports/oil-market-report-march-2020>

International Monetary Fund (IMF) 2020a, POLICY RESPONSES TO COVID-19 (Bangladesh), International Monetary Fund (IMF), viewed 12 April 2020, <https://www.imf.org/en/Topics/imf-and-covid19/PolicyResponses-to-COVID-19\#B>

International Monetary Fund (IMF) 2020b, IMFBlog: An Early View of the Economic Impact of the Pandemic in 5 Charts, International Monetary Fund (IMF), viewed 12 April 2020, <https://blogs.imf.org/2020/04/06/anearly-view-of-the-economic-impact-of-the-pandemic-in-5-charts/>

Ishty, S. I. 2020, 'Your order has been cancelled': The Coronavirus impact on the RMG sector', The Financial Express, 23 March, viewed 9 April 2020, <https://thefinancialexpress.com.bd/views/views/your-order-hasbeen-cancelled-the-coronavirus-impact-on-the-rmg-sector-1584974682>

Islam, M. E., Sultana, M., \& Kamal, A. M. 2013, 'Economic Recession and Its Impact on Bangladesh's Economy with A Special References of RMG and Remittance Sectors', International Journal of Science and Research, vol. 2, no.12, $\quad$ viewed $\quad 14$ April $<$ https://pdfs.semanticscholar.org/b3b7/da35f9a37f78412346294fd2fc4c360bb1c1.pdf $>$

Koirala, J., \& Acharya, S. 2020, 'Impact of Novel Corona Virus (COVID-19 or 2019-nCoV) on Nepalese Economy', SSRN, http://dx.doi.org/10.2139/ssrn.3560638

Koshle, H., Kaur, R. and Basista, R., 2020, 'Breakdown of Business and Workers in India: Impact of Corona Virus', SSRN, http://dx.doi.org/10.2139/ssrn.3557544

Lee, J. W., \& McKibbin, W. J. 2004, 'Estimating the global economic costs of SARS. In Learning from SARS: preparing for the next disease outbreak', workshop summary (p. 92) Washington, DC: National Academies Press, viewed on 9 April 2020, < https://www.ncbi.nlm.nih.gov/books/NBK92473/>

McKibbin, W. J., \& Fernando, R. 2020, 'The global macroeconomic impacts of COVID-19: Seven scenarios', SSRN, http://dx.doi.org/10.2139/ssrn.3547729

McCloskey, B., \& Heymann, D. L. 2020, 'SARS to novel coronavirus-old lessons and new lessons', Epidemiology \& Infection, vol. 148, https://doi.org/10.1017/S0950268820000254

Ministry of Finance (MoF) 2019, Budget at a glance (2019-20), Ministry of Finance (MoF), viewed 9 April 2020,<https://mof.gov.bd/sites/default/files/files/mof.portal.gov.bd/budget_mof/61fa2d4c_f1ca_4f81_9ac4_ 0bb3f7365a3c/St_Summary_Eng.pdf $>$

National Board of Revenue (NBR) 2020, Revenue collection FY2019-20 (up to December, 2019), National Board $\begin{array}{llllll}\text { of } & \text { Revenue } & \text { (NBR), } & \text { viewed } & 14 & \text { April }\end{array}$ http://nbr.gov.bd/uploads/publications/IMG_20200126_0013.pdf>

Organization for Economic Co-operation and Development (OECD) 2020a\&b, OECD Interim Economic Assessment: Coronavirus: The world economy at risk, Organization for Economic Co-operation and Development, viewed 10 April 2020, <https://www.oecd.org/berlin/publikationen/Interim-EconomicAssessment-2-March-2020.pdf>

Organization of the Petroleum Exporting Countries (OPEC) 2020, OPEC Monthly Oil Market report, Organization of the Petroleum Exporting Countries (OPEC), viewed 15 April 2020 $<$ https://www.opec.org/opec_web/static_files_project/media/downloads/publications/OPEC_MOMR_Mar_ 2020.pdf>

The World Bank (WB) 2020a, East Asia and Pacific: Countries Must Act Now to Mitigate Economic Shock of COVID-19, The Word Bank (WB), viewed 14 April 2020, <https://www.worldbank.org/en/news/pressrelease/2020/03/30/east-asia-and-pacific-countries-must-act-now-to-mitigate-economic-shock-of-covid-19>

The World Bank (WB) 2020b, Bangladesh Must Ramp Up COVID-19 Action to Protect its People, Revive 
Economy, The World Bank (WB), viewed 14 April 2020, <https://www.worldbank.org/en/news/pressrelease/2020/04/12/bangladesh-must-act-now-to-lessen-covid-19-health-impacts $>$

United Nations Conference on Trade and Development (UNCTAD) 2020a, World Economic Situation Prospect, United Nations Conference on Trade and Development (UNCTAD), viewed 13 April 2020, $<$ https://unctad.org/en/PublicationsLibrary/wesp2020 en.pdf $>$

United Nations Conference on Trade and Development (UNCTAD) 2020b, Coronavirus outbreak has cost global value chains $\$ 50$ billion in exports, United Nations Conference on Trade and Development (UNCTAD), viewed 9 April 2020, < https://unctad.org/en/pages/newsdetails.aspx?OriginalVersionID=2297>

United Nations Conference on Trade and Development (UNCTAD) 2020c, Coronavirus could cut global investment by $40 \%$, new estimates show, United Nations Conference on Trade and Development (UNCTAD), viewed 10 April 2020, < https://unctad.org/en/pages/newsdetails.aspx?OriginalVersionID=2313>

United Nations Department of Economic and Social Affairs (UNDESA) 2020, World Economic Situation And Prospects: April 2020 Briefing, No. 136, United Nations Department of Economic and Social Affairs (UNDESA), viewed 9 April 2020, <https:/www.un.org/development/desa/dpad/publication/worldeconomic-situation-and-prospects-april-2020-briefing-no-136/>

Worldometers 2020, COVID-19 Coronavirus Pandemic, Worldometers, viewed 04 April 2020, $<$ https://www.worldometers.info/coronavirus/ $>$

World Economic Forum (weforum) 2020a, Coronavirus deaths in Italy overtake China as economic damage mounts, World Economic Forum (weforum), viewed 12 April 2020, $<$ https://www.weforum.org/agenda/2020/03/coronavirus-deaths-italy-china-recession-economy/>

World Economic Forum (weforum) 2020b, Trapped tourists: how is the coronavirus affecting travel?, World Economic Forum (weforum), viewed 12 April 2020, <https://www.weforum.org/agenda/2020/02/thecoronavirus-will-hit-the-tourism-and-travel-sector-hard/>

World Health Organization (WHO) 2020, WHO Director-General's opening remarks at the media briefing on COVID-19, World Health Organization (WHO), viewed 12 April 2020, $<$ https://www.who.int/dg/speeches/detail/who-director-general-s-opening-remarks-at-the-media-briefingon-covid-19---11-march-2020>

World Trade Organization (WTO) 2020, Trade forecast press conference, Remarks by DG Azevêdo, World Trade Organization (WTO), viewed 10 April 2020, <https://www.wto.org/english/news_e/spra_e/spra303_e.htm>

World Tourism Organization (UNWTO) 2020, INTERNATIONAL TOURIST ARRIVALS COULD FALL BY 20$30 \%$ IN 2020, World Tourism Organization (UNWTO), viewed 12 April 2020, $<$ https://www.unwto.org/news/international-tourism-arrivals-could-fall-in-2020> 